\title{
Human parvovirus B 19 co-infection aggravates liver dysfunction in patients with chronic Hepatitis B infection
}

\author{
Yogita Verma', Ekta Gupta', Harsha Vardhan Reddy', Neha Ballani', Meenu Bajpai², \\ Ajeet Singh Bhadoria ${ }^{3}$ \\ ${ }^{1}$ Department of Virology, ${ }^{2}$ Department of Transfusion Medicine and \\ ${ }^{3}$ Department of Research Institute of Liver \& Biliary Sciences Vasant Kunj, New Delhi, India
}

\begin{abstract}
Background and objectives: Human parvovirus B19 (B19) has been reported to be detected in the sera of patients with acute or chronic hepatitis. The aim of this study was to investigate the prevalence of parvovirus B19 in patients with chronic hepatitis B virus $(\mathrm{CHB})$ and hepatitis $C$ virus $(\mathrm{CHC})$ infection and understand its clinical significance. M aterials and methods: Plasma samples from 40 adult chronic hepatitis patients $(20 \mathrm{CHB}$ and $20 \mathrm{CHC}$ ) and 20 healthy blood donors were investigated for antibodies to B19 (IgM and IgG both). Active viremia was confirmed in IgM positive patients by real time PCR for parvovirus B19. Results: IgG antibodies to B19 were seen in $5(25 \%)$ $\mathrm{CHB}, 10(50 \%) \mathrm{CHC}$ and $10(50 \%)$ healthy controls. IgM antibodies to B19 were seen in 3 (15\%) CHB, 5 (25\%) $\mathrm{CHC}$ and $1(5 \%)$ controls. The liver dysfunction was significantly higher in B19 co-infected CHB patients. The serum ALT levels (Median 416.0, IQR 64.0-496.6 IU/L) and AST levels (Median 325, IQR 61.00- 380.00 IU/L) among B19 co-infected CHB patients were significantly higher than serum ALT levels (Median 43.0, IQR 33.0-61.5 IU/L) ( $p=0.023$ ) and serum AST levels (Median 31 (26.50-53.00) IU/) ( $\mathrm{p}=0.013)$ in CHB mono-infected patients However the difference in serum bilirubin levels was not significant amongst the two groups $(p=0.25)$. No aggravation of liver dysfunction was seen in B19 co-infected CHC patients. Interpretation and concl usions: Parvovirus B19 is prevalent equally amongst HBV, HCV infected and healthy population. Co-infection of B19 with HCV did not increase the frequency of liver dysfunction but it definitely aggravates the liver dysfunction in $\mathrm{CHB}$ co-infected patients.
\end{abstract}

Keywords: Chronic hepatitis B infection, chronic hepatitis C infection, parvovirus B19 infection

\section{INTRODUCTION}

Human parvovirus B19 is a DNA virus and is the type member of the erythrovirus genus of family Parvoviridae.

Corresponding author: Ekta Gupta

E-mail: ektagaurisha@gmail.com

Received: 19-02-2016

Accepted: 22-03-2016

How to cite this article: Verma Y, Gupta E, Reddy HV, Ballani N, Bajpai M, Bhadoria AS. Human parvovirus B19 co-infection aggravates liver dysfunction in patients with chronic Hepatitis B infection. J Gastrointest Infect, 2016; 6:32-36
Parvovirus B19 propagates mainly in the erythroid progenitor cells and is a known etiologic agent of erythema infectiosum (fifth disease) and fever with rash illness in pediatric age group. ${ }^{[1,2]}$ The sero-prevalence is reported to be nearly $50 \%$ in adult population. ${ }^{[2]}$ Blood transfusion and close contact are the modalities of effective transmission of the virus. Following exposure to the virus, viremia appears early and lasts approximately 6-8 days. IgM antibodies appear first with 1-2 weeks time and last for 1-2 months. IgG antibodies appear after 2-3 weeks and may persist for several years; therefore their presence indicates a past exposure.$^{[3]}$ The spectrum of liver involvement caused by parvovirus B 19 includes transient 
elevation of transaminases, acute hepatitis, fulminant liver failure and chronic hepatitis. ${ }^{[4-7]}$ Parvovirus B19 DNA and antibodies against it have been detected in patients with chronic hepatitis $\mathrm{B}(\mathrm{CHB})$ or chronic hepatitis $\mathrm{C}(\mathrm{CHC})$ virus infection. ${ }^{[8-10]}$ However the exact association of parvovirus B19 co-infection in $\mathrm{CHB}$ or $\mathrm{CHC}$ infected patients and its effect on liver functions is still controversial. ${ }^{[5,8]}$ A few studies have concluded that persistent parvovirus infection in chronic hepatitis directly correlates with the extent of liver involvement and the probability of progression to more severe hepatitis is significantly higher in such patients. ${ }^{[7.19]}$ On the other hand others have maintained that persistent parvovirus B19 infection does not cause worsening of liver functions in such patients. ${ }^{[4]}$

Hepatitis B virus (HBV) infection is a serious global health problem, with two billion people infected worldwide, and 350 million suffering from CHB infection. ${ }^{[11]}$ Globally, $\mathrm{HBV}$ and hepatitis $\mathrm{C}$ virus (HCV) together are estimated to have led to 500 million chronically infected persons and one million deaths annually. ${ }^{[12]}$ In India, nearly $3-4 \%$ of the population is infected by HBV, and CHB constitutes more than $50 \%$ of the chronic hepatitis cases in the country ${ }^{[13,14]}$ The population prevalence of $\mathrm{HCV}$ infection in India is $1 \%$ and constitutes of nearly $40 \%$ cases of chronic hepatitis. ${ }^{[15,16]}$ Seroprevalence of parvovirus B19 in healthy blood donors has been reported to be $27 \%$ to $40 \%$ in various studies in Indian population. ${ }^{[17,18]}$ However, there is no published data from India regarding the role parvovirus B19 co-infection with $\mathrm{HBV} / \mathrm{HCV}$ in aggravating chronic hepatitis.

The aim of this study was to investigate the prevalence of parvovirus B19 in patients with $\mathrm{CHB}$ and $\mathrm{CHC}$ infection and understand its clinical significance

\section{MATE RIALS AND METHODS}

Research question: The research question for this study was to document the prevalence of parvovirus B19 virus among $\mathrm{HBV}$ and HCV infected patients and to find out whether the presence of this virus affects the clinical course of chronic hepatitis.

Study design: It was a cross-sectional study design. It was a pilot study with 20 cases in each group.

Duration: The duration of this study was January 2014January 2015.

Study subjects: Blood samples were collected from symptomatic hepatitis patients attending to the outpatient and inpatient services of our Institute and healthy blood donors. Diagnosis of $\mathrm{CHB}$ or $\mathrm{CHC}$ infection was based on the presence of hepatitis B surface antigen (HBsAg) or anti-HCV antibodies (anti-HCV) for $>6$ months. All the patients were also biopsy confirmed $\mathrm{CHB}$ or $\mathrm{CHC}$ cases. Patients with chronic hepatitis other than $\mathrm{CHB}$ or $\mathrm{CHC}$ (e.g alcoholic liver disease, autoimmune hepatitis, others) were excluded from the study.

A total of 60 subjects were included in the study: $20 \mathrm{CHB}$ and $20 \mathrm{CHC}$ and 20 healthy age matched blood donors.

Sample collection: Twenty milliliters of blood was collected in EDTA (Ethylene diamine tetra acetic acid) vials from each patient. Plasma was separated and kept at $-80^{\circ} \mathrm{C}$ till further testing.

Parvovirus B19 antibody detection: $\operatorname{IgM}$ and $\operatorname{IgG}$ antibodies against parvovirus B19 were detected in the plasma samples using ELISA classic parvovirus B19 $\mathrm{IgG} / \mathrm{IgM}$ kit (Serion Immundiagnostica $\mathrm{GmbH}$, Germany) according to the manufacturer's instructions. The test results were interpreted according to the kit literature and samples were reported as reactive or non-reactive.

DNA extraction and polymerase chain reaction (PCR): Viral DNA was extracted using High Pure Viral Nucleic Acid Kit (Roche Diagnostics GmbH, Roche Applied Science. Germany) as per the manufacturer's instructions. Real time PCR was done to detect parvovirus DNA in the plasma samples using AmpliSens parvovirus B19-FRT PCR kit (Federal Budget Institute of Science "Central Research Institute for Epidemiology", Russia). The reaction mixture containing PCR-mix-1-FRT parvovirus B19, PCR-mix-2FRT, polymerase (TaqF) was added to $10 \mu \mathrm{l}$ volume of the extracted DNA sample to make the total reaction volume of 25 $\mu \mathrm{l}$. The cycling conditions used were: Holding at $95^{\circ} \mathrm{C}$ for 15 minutes followed by 5 cycles $\left(95^{\circ} \mathrm{C}\right.$ for $5 \mathrm{~s}, 60^{\circ} \mathrm{C}$ for $20 \mathrm{~s}$ and $72^{\circ} \mathrm{C}$ for $\left.15 \mathrm{~s}\right)$ and 40 cycles $\left(95^{\circ} \mathrm{C}\right.$ for $5 \mathrm{~s}, 60^{\circ} \mathrm{C}$ for $30 \mathrm{~s}$ and $72^{\circ} \mathrm{C}$ for $15 \mathrm{~s}$ ). Linear range of the assay is $10^{2}-10^{7} \mathrm{IU} / \mathrm{ml}$.

For the detection of HBV DNA/HCV RNA in CHB/CHC groups respectively, viral DNA/RNA was extracted using High Pure Viral Nucleic Acid Kit (Roche Diagnostics $\mathrm{GmbH}$, Roche Applied Science, Germany) as per the manufacturer's instructions and Real time PCR was performed to detect HBV DNA/ HCV RNA in the plasma samples using COBAS TaqMan 48 Analyser (Roche Diagnostics, North America).

Liver function tests: Alanine transaminase (ALT) and aspartate aminotransferase (AST) levels were determined in the patient sera using UniCel® DxC 600 (Beckman Coulter, Inc, Ireland)

Statistical analysis: Statistical analysis was done using the SPSS software version 22.0. Data was described in terms of mean $( \pm 2 \mathrm{SD})$, median (interquartile range) and percentage. Non-parametric tests namely Mann Whitney U-test and Fisher's exact were used to compare the sets of data.

Ethical considerations: A written and informed consent was 
Table 1

Baseline characteristics of the study population

\begin{tabular}{|c|c|c|c|}
\hline Parameter & $\mathrm{CHB}(\mathrm{n}=20)$ & CHC $(n=20)$ & $\begin{array}{l}\text { Control } \\
(n=20)\end{array}$ \\
\hline Number & 20 & 20 & 20 \\
\hline Male: female & $14: 6$ & 11:9 & $12: 8$ \\
\hline $\begin{array}{l}\text { Mean age in } \\
\text { years } \\
( \pm 2 S D)\end{array}$ & $38( \pm 11.09)$ & $44( \pm 12.4)$ & $40( \pm 11.3)$ \\
\hline $\begin{array}{l}\text { B19 IgM +ve, } \\
\text { n (\%) }\end{array}$ & $3(15 \%)$ & $5(25 \%)$ & $1(5 \%)$ \\
\hline $\begin{array}{l}\text { B19 IgG +ve, } \\
\text { n(\%) }\end{array}$ & $5(25 \%)$ & $10(50 \%)$ & $10(50 \%)$ \\
\hline $\begin{array}{l}\text { Median AST } \\
\text { levels (IU/L) } \\
\text { (Range) }\end{array}$ & $\begin{array}{l}36.00(27.25- \\
60.00)\end{array}$ & $\begin{array}{l}54.00(37.00- \\
87.50)\end{array}$ & $\begin{array}{l}20(18.25- \\
25.00)\end{array}$ \\
\hline $\begin{array}{l}\text { Median ALT } \\
\text { levels } \\
\text { (IU/L)(Range) }\end{array}$ & $\begin{array}{l}46.50(33.25- \\
92.5)\end{array}$ & $\begin{array}{l}50.00(35.00- \\
95.5)\end{array}$ & $\begin{array}{l}22(17.25- \\
26.00)\end{array}$ \\
\hline $\begin{array}{l}\text { Median bilirubin } \\
\text { levels } \\
(\mathrm{mg} / \mathrm{dl})\end{array}$ & $\begin{array}{l}0.80(0.70- \\
1.47)\end{array}$ & $\begin{array}{l}0.90(0.70- \\
1.57)\end{array}$ & $\begin{array}{l}0.7(0.60- \\
0.87)\end{array}$ \\
\hline $\begin{array}{l}\text { Median viral } \\
\text { load(DNA/ } \\
\text { RNA })(\text { IU/ml })\end{array}$ & $\begin{array}{l}2.06 ? 1^{5} 0(2.03 \\
? 10^{4}-7.35 ? \quad 10\end{array}$ & $\begin{array}{l}9.35 ? 1^{5} 0(4.77 \\
? 10^{5}-1.57 ? 10\end{array}$ & - \\
\hline
\end{tabular}

$\mathrm{CHB}=$ Chronic Hepatitis $\mathrm{B}, \mathrm{CHC}=$ Chronic Hepatitis $\mathrm{C}, \mathrm{SD}=$ Standard deviation, AST $=$ aspartate transaminase, $\mathrm{ALT}=$ alanine transaminase, IU= International Units

obtained from all the patients participating in the study. An approval from the institutional ethics committee was obtained.

\section{RESULTS}

\section{Baseline characteristics of the study population}

The baseline characteristics of the study population are depicted in Table 1 . The study population consisted of 20 CHB, 20 CHC patients and 20 healthy controls. Overall mean age of the study population comprising of 37 males and 23 females was $41( \pm 11.8)$ years.

In CHB group, median HBV DNA levels were 2.06 ? $10^{5}$ (2.03 ? $\left.10^{4}-7.35 ? 10^{6}\right) \mathrm{IU} / \mathrm{ml}$ and all were genotype D isolates. $40 \%$ were $\mathrm{HBe}$ antigen positive. In the $\mathrm{CHC}$ group, median HCV RNA levels were 9.35 ? $10^{5}$ (4.77? 10 - 1.57 ?

$\left.10^{6}\right)$. Majority $(80 \%)$ of the CHC patients were genotype 3 while rests were genotype 1 .

\section{Seroprevalence of parvovirus B19 in different groups}

In order to determine the seroprevalence of parvovirus B19 in all the groups, parvovirus B19 specific IgG antibodies were tested. No difference in the seroprevalence amongst various groups was seen, 25\% (5/20) in CHB, 50\% (10/20) in CHC and 50\% (10/20) in healthy controls.

IgM antibody positivity, was more in $\mathrm{CHC}$ patients $25 \%$ (5/20) than in CHB patients : 15\% (3/20), or controls 5\% $(1 / 20)$ (Table 1). Parvovirus B19 DNA could not be detected in any of the IgM positive samples. Hence further comparisons were made between parvovirus B19 IgM positive (coinfected) and IgM negative (mono-infected) $\mathrm{CHB}$ and $\mathrm{CHC}$ patients.

Comparison of liver function abnormality between parvovirus B19 co-infected and mono-infected CHB patients

In the CHB patients, the difference in median values of ALT and AST (signifying the liver dysfunction) amongst the patients with parvovirus co-infection $(\operatorname{IgM}+\mathrm{ve})$ and monoinfected (IgM negative) was found to be significant (Fig.1). However the total bilirubin levels in the two groups was insignificant. Similarly, the difference in Hepatitis B viral load (signifying viral replication) was insignificant in the two groups (Table 2). The number of $\mathrm{HBe} \mathrm{Ag}$ positive patients was 2/3(66.7\%) amongst the parvovirus B19 co-infected patients

Fig. 1(a-e): Comparison of liver function tests and viral load between the parvovirus B19 co-infected and HBV mono-infected patients amongst the CHB patients.

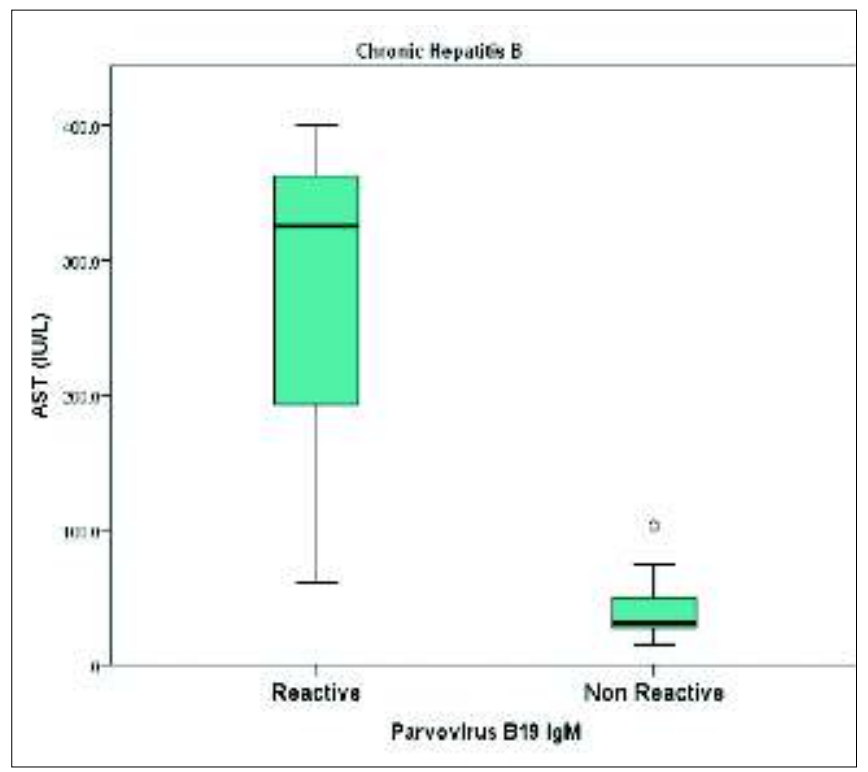

Fig. 1a: Comparison of serum AST levels between parvovirus B19 co-infected and HBV mono-infected CHB patients. 
Table 2

Comparison of various parameters in parvovirus B19 co-infected and HBV/HCV mono-infected patients

\begin{tabular}{|c|c|c|c|c|c|c|c|}
\hline \multirow{2}{*}{$\begin{array}{l}\text { S. } \\
\text { no }\end{array}$} & \multirow[t]{2}{*}{ Parameter } & \multirow{2}{*}{$\begin{array}{l}\text { CHB patients } \\
\text { Parvovirus } \\
\text { B19 IgM +ve }\end{array}$} & \multirow[b]{2}{*}{$\begin{array}{l}\text { Parvovirus } \\
\text { B19 IgM-ve }\end{array}$} & \multirow[t]{2}{*}{ Pvalue* } & \multicolumn{2}{|c|}{ CHC patients } & \multirow{2}{*}{$\begin{array}{l}\mathbf{P} \\
\text { value* }\end{array}$} \\
\hline & & & & & $\begin{array}{l}\text { Parvovirus } \\
\text { B19 IgM +ve }\end{array}$ & $\begin{array}{l}\text { Parvovirus } \\
\text { B19 IgM-ve }\end{array}$ & \\
\hline 1 & $\begin{array}{l}\text { Median AST levels } \\
\text { (IU/L) }\end{array}$ & $\begin{array}{l}325 \\
(61.00-380.00)\end{array}$ & $\begin{array}{l}31 \\
(26.50-53.00)\end{array}$ & 0.013 & $\begin{array}{l}66 \\
(33.50-240)\end{array}$ & $\begin{array}{l}52 \\
(37.00-89.00)\end{array}$ & 0.76 \\
\hline 2 & $\begin{array}{l}\text { Median ALT levels } \\
\text { (IU/L) }\end{array}$ & $\begin{array}{l}416 \\
(64.00 \quad 4-96.50)\end{array}$ & $\begin{array}{l}43 \\
(33.00-61.50)\end{array}$ & 0.023 & $\begin{array}{l}97 \\
(31.00-188.50)\end{array}$ & $\begin{array}{l}48 \\
(35.00-88.00)\end{array}$ & 0.63 \\
\hline 3 & $\begin{array}{l}\text { Median bilirubin } \\
\text { levels(mg/dl) }\end{array}$ & $\begin{array}{l}3.4 \\
(0.50-4.3)\end{array}$ & $\begin{array}{l}0.80 \\
(0.70-1.15)\end{array}$ & 0.25 & $\begin{array}{l}0.9 \\
(0.65-2.75)\end{array}$ & $\begin{array}{l}0.9 \\
(0.7-1.66)\end{array}$ & 1.00 \\
\hline 4 & $\begin{array}{l}\text { Median viral } \\
\operatorname{load}(\mathrm{DNA} / \mathrm{RNA})(\mathrm{IU} / \mathrm{ml})\end{array}$ & $\begin{array}{l}4.83 ? 10 \\
(2.80 ? 10- \\
5.89 ? 10)\end{array}$ & $\begin{array}{l}1.18 ? 10 \\
(1.82 ? 10-9.52 ? \\
\left.10^{6}\right)\end{array}$ & 0.26 & $\begin{array}{l}1.09 ? 10(4.2 \\
\left.? 10^{5}-2.65 ? 10\right)\end{array}$ & $\begin{array}{l}9.4 ? 10^{5}(5.6 ? \\
\left.10^{5}-1.50 ? 10\right)\end{array}$ & 0.76 \\
\hline 5 & $\begin{array}{l}\text { Median HBsAg levels } \\
\text { (IU/ml) }\end{array}$ & $\begin{array}{l}58688(2860- \\
68790)\end{array}$ & $\begin{array}{l}15345 \\
(5731-23779)\end{array}$ & 0.49 & - & - & - \\
\hline
\end{tabular}

*Mann Whitney U- test

$\mathrm{CHB}=$ Chronic Hepatitis $\mathrm{B}, \mathrm{CHC}=$ Chronic Hepatitis $\mathrm{C}, \mathrm{AST}=$ aspartate transaminase, $\mathrm{ALT}=$ alanine transaminase, $\mathrm{IU}=\mathrm{International}$ Units

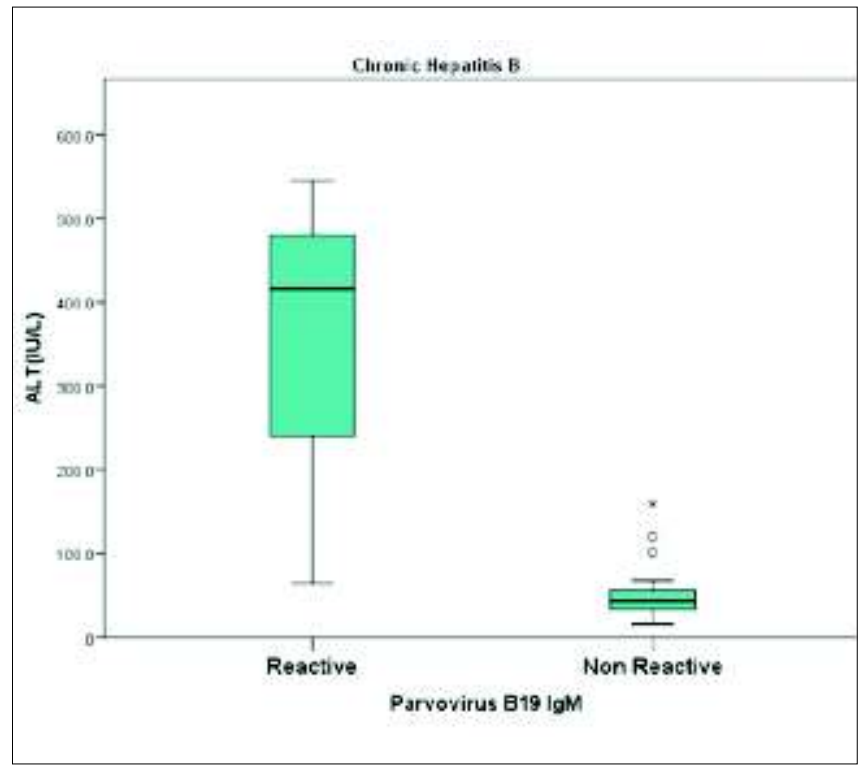

Fig. 1b: Comparison of serum ALT levels between parvovirus B19 co-infected and HBV mono-infected CHB patients.

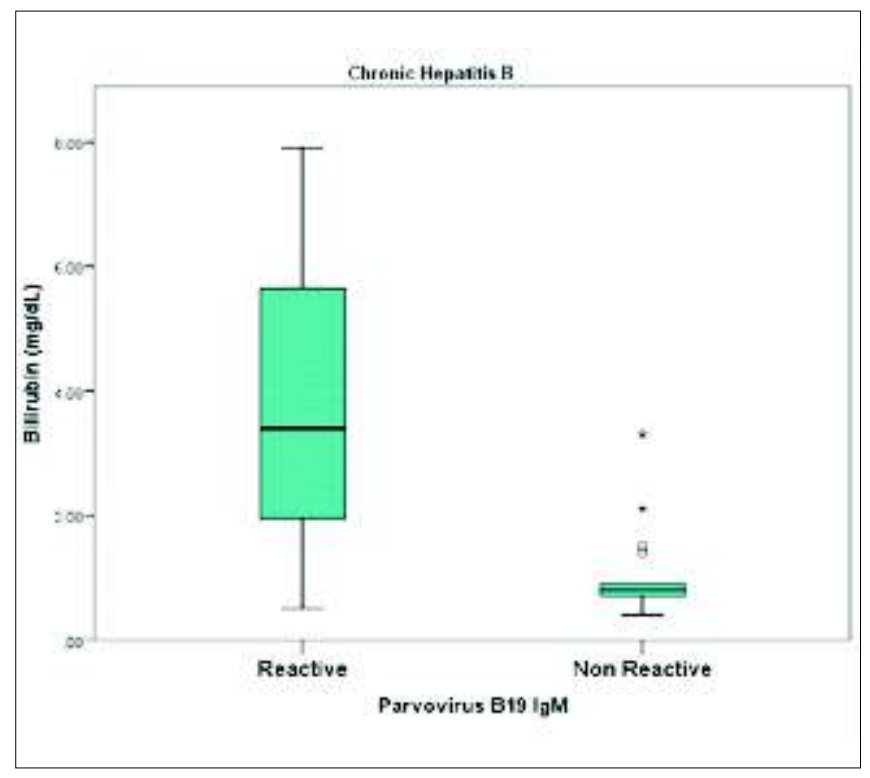

Fig. 1c: Comparison of serum Bilirubin levels between parvovirus B19 co-infected and HBV mono-infected CHB patients. 


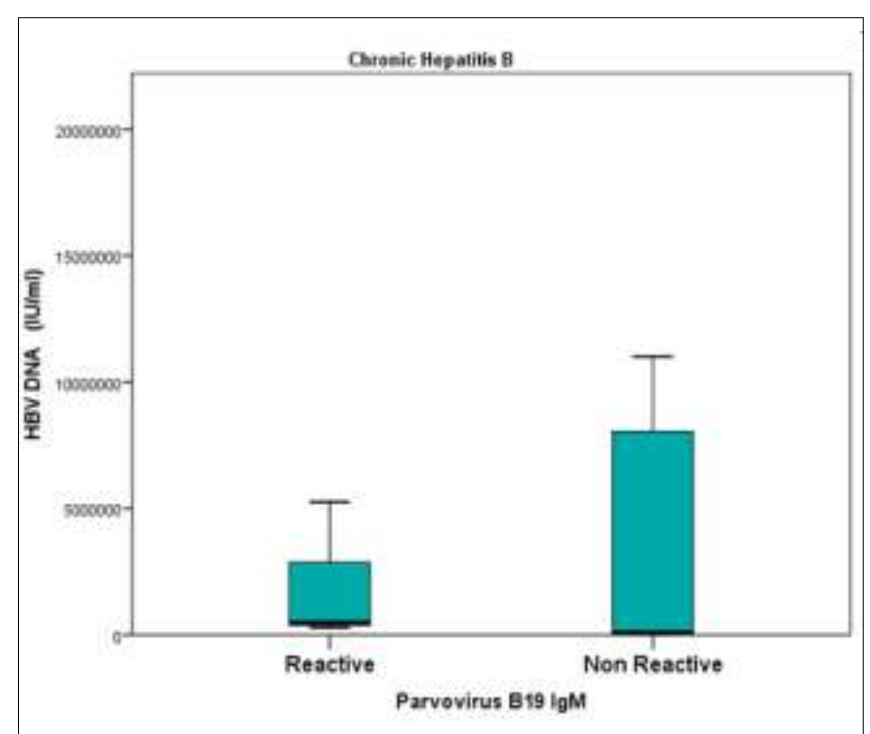

Fig. 1d: Comparison of HBV DNA levels between parvovirus B19 co-infected and HBV mono-infected CHB patients.

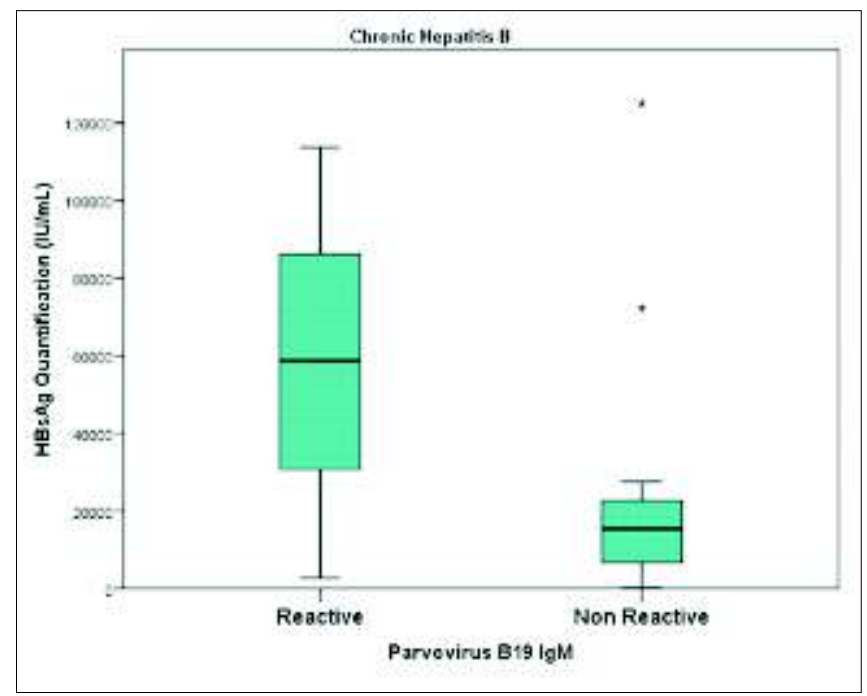

Fig. 1e: Comparison of $\mathrm{HBsAg}$ levels between parvovirus B19 co-infected and HBV mono-infected CHB patients.

and 6/17(35.3\%) amongst the HBV mono-infected. The difference was not statistically significant $(\mathrm{P}=0.53)$.

Amongst the $\mathrm{CHC}$ patients, the difference in median values of ALT, AST, bilirubin and Hepatitis C viral load in patients with co-infection with parvovirus and HCV monoinfected was found to be insignificant (Fig. 2).

\section{DISCUSSION}

Human parvovirus B19 has been reported to be detected in the sera of patients with acute or chronic hepatitis. The seroprevalence of $\mathrm{B} 19$ in $\mathrm{CHB} / \mathrm{CHC}$ patients ranges from $21 \%$ to $47 \% .^{[7,8,10]}$ Acute infection with parvovirus has been
Figure 2(a-d): Comparison of liver function tests and viral load between the parvovirus B 19 co-infected and HCV mono-infected patients amongst the $\mathrm{CHC}$ patients

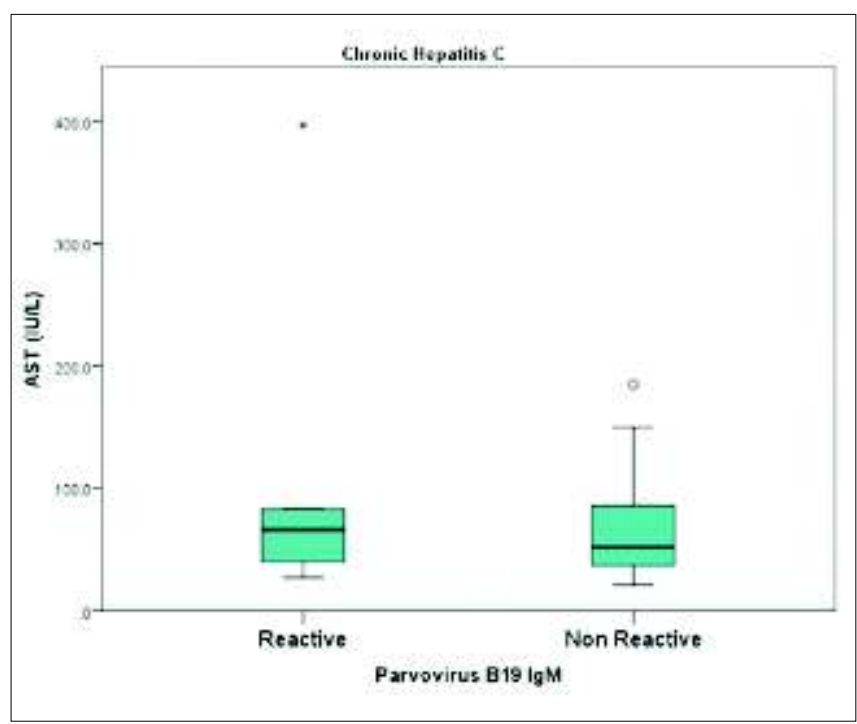

Fig. 2a: Comparison of serum AST levels between parvovirus B19 co-infected and HCV mono-infected CHC patients.

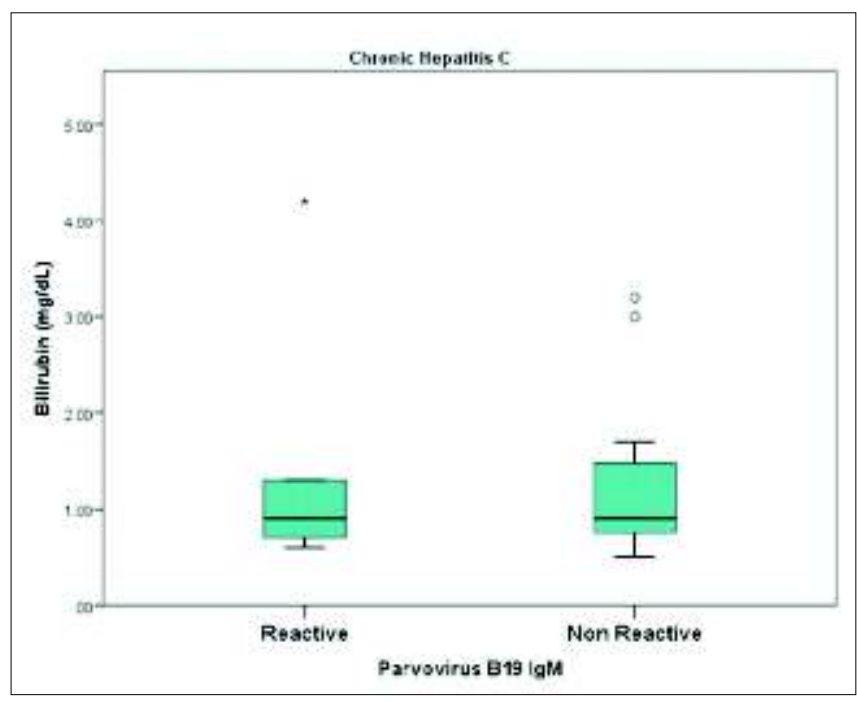

Fig. 2c: Comparison of serum Bilirubin levels between parvovirus B19 co-infected and HCV mono-infected $\mathrm{CHC}$ patients.

reportedly higher in $\mathrm{CHB}$ and $\mathrm{CHC}$ patients. It has been established that it might be difficult to eradicate parvovirus B19 infection from chronic hepatitis patients. The role of parvovirus B19 infection in chronic hepatitis has been debated in various studies. There are published reports concluding that parvovirus B19 persistence in $\mathrm{CHB} / \mathrm{CHC}$ patients positively correlates with liver involvement and increases the probability of worsening of hepatitis and others stating that persistent 


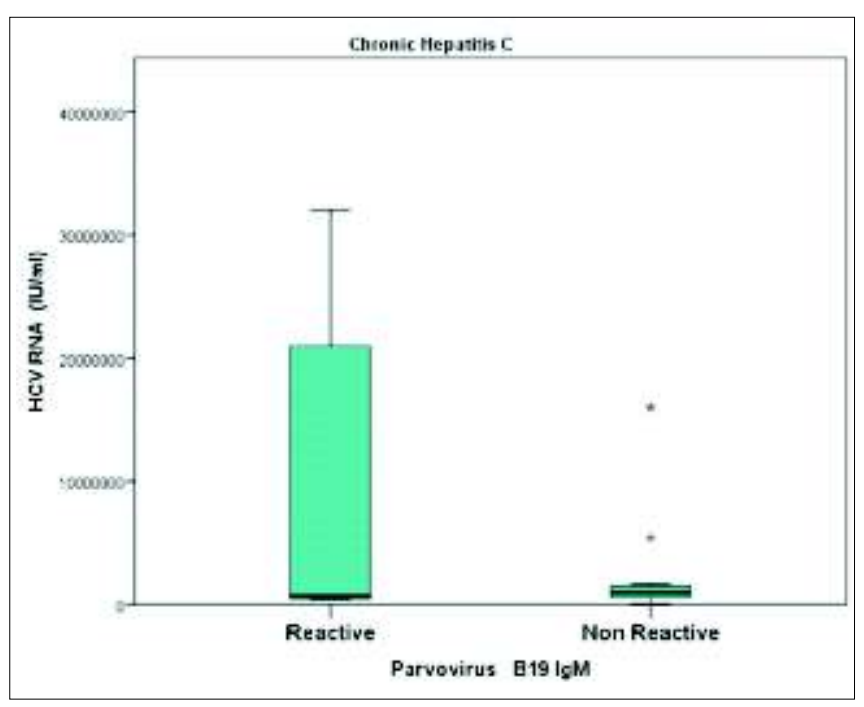

Fig. 2c: Comparison of serum Bilirubin levels between parvovirus B19 co-infected and HCV mono-infected $\mathrm{CHC}$ patients.

parvovirus B19 infection in such patients doesn't worsen liver functions. No association of HBV genotype has been found with parvovirus prevalence in coinfected subjects. ${ }^{[20]}$

In the present study, we found the seroprevalence of parvovirus B19 infection to be similar in healthy controls (50\%) and chronic hepatitis patients $(25 \%$ in $\mathrm{CHB}$ and $50 \%$ in $\mathrm{CHC}$ ). The seroprevalence of parvovirus B19 found in this study is lesser as compared to the population from Vietnam ${ }^{[8]}$ or Taiwan; ${ }^{[7]}$ although similar to the Nigerian population as reported by Opalaye et $a l^{[10]}$ in 2011. However there is no published data from India highlighting the seroprevalence of parvovirus B19 in chronic hepatitis patients.

Acute infection with parvovirus $\operatorname{IgM}+$ ve was found to be higher in $\mathrm{CHB}$ and $\mathrm{CHC}$ patients as compared to controls. This significant difference might be due to the shared routes of infection like blood transfusion and intravenous drug abuse between hepatitis $\mathrm{B}$ virus, hepatitis $\mathrm{C}$ virus and parvovirus B19. Similar association has been reported earlier in the

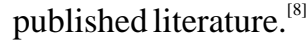

$\mathrm{Yu}$ et $a l^{[20]}$ in a recently published study, reported that parvovirus infection was positively correlated to serum ALT production in $\mathrm{CHB}$ coinfected patients. Toan et $a l^{[7]}$ concluded in a study conducted on 463 hepatitis patients, that in HBV/B19 co-infection the probability of progression to more severe hepatitis is significantly higher. Pongratz et $a l^{[19]}$ reported that parvovirus B19 persistence in chronic hepatitis patients directly correlates with the extent of liver involvement. However, Wang et $a l^{[4]}$ in a study conducted on European patients, reported persistent parvovirus B19 infection in the $\mathrm{CHB}$ and $\mathrm{CHC}$ patients and concluded that the persistence of B19 virus infection does not cause any significant worsening of liver functions in the patients with chronic hepatitis related to $\mathrm{HBV} / \mathrm{HCV}$. In the existing study, the median values of liver enzymes (AST, ALT) were significantly higher in $\mathrm{CHB}$ patients co-infected with parvovirus B19 but not in the case of $\mathrm{CHC}$ patients. The difference in DNA/ RNA levels in the co- infected and monoinfected groups was insignificant in both $\mathrm{CHB}$ and $\mathrm{CHC}$ patients. This suggests that co-infection with parvovirus B19 in $\mathrm{CHB}$ patients might have a role in aggravating the liver dysfunction but a larger sample size and a more detailed study might be needed to establish the same.

The results reflect that co-infection with parvovirus B19 in $\mathrm{CHC}$ patients neither aggravates the ongoing insult to the hepatocytes nor enhances replication rates of HCV. Therefore on the basis of these results the role of parvovirus B19 in aggravating the disease in $\mathrm{CHC}$ seems unlikely.

\section{Limitations of the study}

This is the first study on Indian population which explores the role of parvovirus B19 in chronic hepatitis. However due to small sample size and lack of follow up of the parvovirus B19 co-infected patients to monitor further worsening of liver function we cannot confirm the role of parvovirus B19 in aggravating liver disease. More structured studies should be planned that could provide a better insight into the same.

\section{CONCLUSION}

Parvovirus B19 is prevalent equally amongst HBV, HCV infected and healthy population. Co-infection of parvovirus B19 with HCV did not increase the frequency of liver dysfunction but it definitely aggravates the liver dysfunction in $\mathrm{CHB}$ co-infected patients.

\section{CONFLICTS OF INTEREST: None}

\section{REFERENCES}

1. Chorba T, Coccia P, Holman RC, Tattersall P, Anderson LJ, Sudman $\mathrm{J}$ et al. The role of parvovirus B19 in aplastic crisis and erythema infectiosum (fifth disease). J Infect Dis. 1986;154:38393.

2. Young NS, Brown KE. Parvovirus B19. N Engl J Med.2004; 350:586-97.

3. Gallinella G, Zuffi E, Gentilomi G, Manaresi E, Venturoli S, Bonvicini $F$ et al. Relevance of B19 markers in serum samples for a diagnosis of parvovirus B19-correlated diseases. J Med Virol. 2003;71:135-9.

4. Wang C, Heim A, Schlaphoff V, Suneetha PV, Stegmann KA, Jiang $\mathrm{H}$ et al. Intrahepatic long term persistence of parvovirus B19 and its role in chronic viral hepatitis. J Med Virol. 2009;81: 2079-88.

5. Krygier S, Steinbrecher UP, Petric M, Erb SR, Chung SW, Scudamore $\mathrm{CH}$ et al. Parvovirus B19 induced hepatic failure in an 
adult requiring liver transplantation. World J Gastroenterol. 2009;15:4067-69.

6. Kim BJ, Yoo KH, Li K, Kim MN. Parvovirus B19 infection associated with acute hepatitis in infant. Pediatr Infect Dis J.2009;28:667.

7. Toan NL, Song LH, Kremsner PG, Duy DN, Binh VQ, Duechting A et al. Co-infection of human parvovirus B19 in Vietnamese patients with hepatitis B virus infection. J Hepatol. 2006;45: 361-69.

8. Hsu TC, Chen TY, Lin MC, Tzang BS, Tsay GJ. Human parvovirus B19 infection in patients with chronic hepatitis B or hepatitis C infection. J Gastroenterol Hepatol. 2005;20:733-38.

9. Mogensen $\mathrm{TH}$, Jensen JM, Hamilton-Dutoit S, Larsen CS. Chronic hepatitis caused by persistent parvovirus B19 infection. BMC infectious diseases. 2010;10:246.

10. Opaleye OO, Fagbami AH, Lalremruata A, Kun JF. Prevalence and association of human parvovirus $\mathrm{B} 19 \mathrm{~V}$ with hepatitis $\mathrm{B}$ and $\mathrm{C}$ viruses in Nigeria. J Med Virol. 2011;83:710-16.

11. Lavanchy D. Hepatitis B virus epidemiology, disease burden, treatment, and current and emerging prevention and control measures. J Viral Hepat. 2004;11:97-107.

12. World Health Organisation. Global policy report on the prevention and control of viral hepatitis in WHO member states. 2013 July.
13. Chowdhury A. Epidemiology of hepatitis $B$ virus infection in India. Hep B Annual. 2004;1:17-24.

14. Batham A, Narula D, Toteja T, Sreenivas V, Puliyel JM. Sytematic review and meta-analysis of prevalence of hepatitis $B$ in India. Indian Pediatr. 2007;44:663-74.

15. Saravanan S, Velu V, Kumarasamy N, Shankar EM, Nandakumar $\mathrm{S}$, Murugavel KG et al. The prevalence of hepatitis $B$ virus and hepatitis $C$ virus infection among patients with chronic liver disease in South India. Int J Infect Dis. 2008;12:513-18.

16. Arora D, Jindal N, Dang R, Kumar R. Rising sero-prevalence of HCV a silent killer: emerging problem. Int J Pharm Pharm Sci. 2011;3:57-59.

17. Sharad S, Kapur S. Emerging Human Infections: An Overview on Parvovirus B19. Journal, Indian Academy of Clinical Medicine. 2005;6:319-26.

18. Kumar S, Gupta RM, Sen S et al. Seroprevalence of human parvovirus B19 in healthy blood donors. Med J Armed Forces India. 2013;69:268-72.

19. Pongratz G, Lindner J, Modrow S, Schimanski S, Scholmerich J, Fleck M. Persistent parvovirus B19 infection detected by specific CD4+ T-cell responses in a patient with hepatitis and polyarthritis. J Intern Med. 2009;266:296-301.

20. Yu X, Wang J, Zhao B, Ghildyal R. PARV-4 coinfection is associated with disease progression in HBV patients in Shanghai. J. Med. Diagn Meth. 2015;4:168. 